University of Nebraska - Lincoln

DigitalCommons@University of Nebraska - Lincoln

\title{
Greenhouse Gas Emissions from Two Soils Receiving Nitrogen Fertilizer and Swine Manure Slurry
}

\author{
Marek K. Jarecki \\ AgCert USA, marek.jarecki@ars.usda.gov \\ Timothy B. Parkin \\ USDA-ARS-NSTL \\ Alvarus S. K. Chan \\ AgCert USA \\ Jerry L. Hatfield \\ USDA-ARS-NSTL, jerry.hatfield@ars.usda.gov \\ Raymond Jones \\ AgCert Canada
}

Follow this and additional works at: https://digitalcommons.unl.edu/usdaarsfacpub

Jarecki, Marek K.; Parkin, Timothy B.; Chan, Alvarus S. K.; Hatfield, Jerry L.; and Jones, Raymond, "Greenhouse Gas Emissions from Two Soils Receiving Nitrogen Fertilizer and Swine Manure Slurry" (2008). Publications from USDA-ARS / UNL Faculty. 1364.

https://digitalcommons.unl.edu/usdaarsfacpub/1364

This Article is brought to you for free and open access by the U.S. Department of Agriculture: Agricultural Research Service, Lincoln, Nebraska at DigitalCommons@University of Nebraska - Lincoln. It has been accepted for inclusion in Publications from USDA-ARS / UNL Faculty by an authorized administrator of DigitalCommons@University of Nebraska - Lincoln. 


\section{Greenhouse Gas Emissions from Two Soils Receiving Nitrogen Fertilizer and Swine Manure Slurry}

\author{
Marek K. Jarecki* AgCert USA \\ Timothy B. Parkin USDA-ARS-NSTL \\ Alvarus S. K. Chan AgCert USA \\ Jerry L. Hatfield USDA-ARS-NSTL \\ Raymond Jones AgCert Canada
}

The interactive effects of soil texture and type of $\mathrm{N}$ fertility (i.e., manure vs. commercial $\mathrm{N}$ fertilizer) on $\mathrm{N}_{2} \mathrm{O}$ and $\mathrm{CH}_{4}$ emissions have not been well established. This study was conducted to assess the impact of soil type and $\mathrm{N}$ fertility on greenhouse gas fluxes $\left(\mathrm{N}_{2} \mathrm{O}, \mathrm{CH}_{4}\right.$, and $\left.\mathrm{CO}_{2}\right)$ from the soil surface. The soils used were a sandy loam $\left(789 \mathrm{~g} \mathrm{~kg}^{-1}\right.$ sand and $138 \mathrm{~g} \mathrm{~kg}^{-1}$ clay) and a clay soil (216 g kg $\mathrm{g}^{-1}$ sand, and $415 \mathrm{~g} \mathrm{~kg}^{-1}$ clay). Chamber experiments were conducted using plastic buckets as the experimental units. The treatments applied to each soil type were: (i) control (no added N), (ii) urea-ammonium nitrate (UAN), and (iii) liquid swine manure slurry. Greenhouse gas fluxes were measured over 8 weeks. Within the UAN and swine manure treatments both $\mathrm{N}_{2} \mathrm{O}$ and $\mathrm{CH}_{4}$ emissions were greater in the sandy loam than in the clay soil. In the sandy loam soil $\mathrm{N}_{2} \mathrm{O}$ emissions were significantly different among all $\mathrm{N}$ treatments, but in the clay soil only the manure treatment had significantly higher $\mathrm{N}_{2} \mathrm{O}$ emissions. It is thought that the major differences between the two soils controlling both $\mathrm{N}_{2} \mathrm{O}$ and $\mathrm{CH}_{4}$ emissions were cation exchange capacity (CEC) and percent water-filled pore space (\%WFPS). We speculate that the higher CEC in the clay soil reduced $\mathrm{N}$ availability through increased adsorption of $\mathrm{NH}_{4}^{+}$compared to the sandy loam soil. In addition the higher average \%WFPS in the sandy loam may have favored higher denitrification and $\mathrm{CH}_{4}$ production than in the clay soil.
Copyright $\odot 2008$ by the American Society of Agronomy, Crop Science Society of America, and Soil Science Society of America. All rights reserved. No part of this periodical may be reproduced or transmitted in any form or by any means, electronic or mechanical, including photocopying, recording, or any information storage and retrieval system, without permission in writing from the publisher.

Published in J. Environ. Qual. 37:1432-1438 (2008). doi:10.2134/jeq2007.0427

Received 13 Aug. 2007.

*Corresponding author (marek.jarecki@ars.usda.gov). (c) ASA, CSSA, SSSA

677 S. Segoe Rd., Madison, WI 53711 USA
$T$ OTAL emissions of greenhouse gasses (GHGs) can be significantly altered by agricultural practices. Increases in $\mathrm{N}_{2} \mathrm{O}$ flux are impacted by human activity (Rochette et al., 2000), and it has been estimated that agriculture contributes from 60 to $80 \%$ of total $\mathrm{N}_{2} \mathrm{O}$ emissions on a global scale (Isermann, 1994; Janzen et al., 1998; Cameron et al., 2000; Dalal et al., 2003). A major factor influencing $\mathrm{N}_{2} \mathrm{O}$ emissions from agricultural lands is $\mathrm{N}$ application (Mosier et al., 1982; Kaiser et al., 1998; Rochette et al., 2000; de Klein et al., 2001; Yamulki and Jarvis, 2002; Dalal et al., 2003). Nitrogen fertilization can significantly enhance $\mathrm{N}_{2} \mathrm{O}$ emissions and it is generally recognized that as $\mathrm{N}$ inputs increase, $\mathrm{N}_{2} \mathrm{O}$ emissions also increase (Mosier et al., 1982; Eichner, 1990). The relationship between $\mathrm{N}$ inputs and $\mathrm{N}_{2} \mathrm{O}$ emissions is commonly described as linear (Bouwman, 1996; Gregorich et al., 2005; IPCC, 2006), although recently, McSwiney and Robertson (2005) present evidence that the relationship between $\mathrm{N}$ inputs and $\mathrm{N}_{2} \mathrm{O}$ emissions may exhibit a threshold effect.

It is also recognized that, despite the common assumption of linearity between $\mathrm{N}$ inputs and $\mathrm{N}_{2} \mathrm{O}$ emissions, soil systems are quite complex (Bouwman et al., 2002; Mosier and Parkin, 2007). The form of $\mathrm{N}$ fertilizer applied has been observed to influence $\mathrm{N}_{2} \mathrm{O}$ emissions (Breitenbeck et al., 1980; Eichner, 1990) as well as $\mathrm{N}$ fertilizer placement in the soil (Bremner et al., 1981). Land application of animal waste also increases $\mathrm{N}_{2} \mathrm{O}$ emission (Mosier et al., 1998; Petersen, 1999). According to Kaiser and Ruser (2000), from 0.74 to $2.86 \%$ of slurry $\mathrm{N}$ was emitted as a $\mathrm{N}_{2} \mathrm{O}$ annually, whereas de Klein et al. (2001) reported annual N- ${ }_{2} \mathrm{O}$ losses of manure $\mathrm{N}$ ranging from 0 to $5 \%$. The largest emission of $\mathrm{N}_{2} \mathrm{O}$ in the range of 100 to $150 \mathrm{~g} \mathrm{~N}_{2} \mathrm{O} \mathrm{ha}^{-1} \mathrm{~d}^{-1}$ occurred within 1 to $2 \mathrm{~d}$ after the injection of slurry (Comfort et al., 1990).

Nitrogen fertilization also reduces soil $\mathrm{CH}_{4}$ oxidation (Steudler et al., 1989; Schimel and Gulledge, 1998). Soils can be a source or a sink for $\mathrm{CH}_{4}$ depending on soil type, aeration, and nitrogen availability (Chan and Parkin, 2001b; Le Mer and Roger, 2001). In upland soils $\mathrm{CH}_{4}$ oxidation is typically greater than methano-

M.K. Jarecki, AgCert USA, National Soil Tilth Lab., 2110 University Ave., Ames, IA 50011. T.B. Parkin and J.L. Hatfield, National Soil Tilth Lab., 2110 University Ave., Ames, IA 50011. A.S.K. Chan, AgCert USA, 1990 W. New Haven Ave., Suite 205, Melbourne, FL 32904. R. Jones, AgCert Canada Co., 309 1st Street W., High River, AB T1V 1M5, Canada.

Abbreviations: CEC, cation exchange capacity; GHG, greenhouse gas; IPCC, Intergovernmental Panel on Climate Change; SOC, soil organic carbon; UAN, urea ammonium nitrate; \%WFPS, percent water-filled pore space. 
genesis (Conrad, 1996; Hütsch, 2001). The potential for different ecosystems to serve as a sink for atmospheric $\mathrm{CH}_{4}$ varies from 1 to $2 \mathrm{~kg} \mathrm{CH}_{4}-\mathrm{C} \mathrm{ha}^{-1} \mathrm{yr}^{-1}$, however, different sources of $\mathrm{N}$ inputs can considerably suppress $\mathrm{CH}_{4}$ oxidation rates (Smith et al., 2000; Suwanwaree and Robertson, 2005).

Pork production is a major agricultural enterprise in the Midwest and results in the production of large quantities of liquid or semi-liquid manure slurry. Direct injection of this swine manure has become a common technique for land application (Hatfield et al., 1998). The greater contact of injected slurry with soil can induce favorable conditions for $\mathrm{N}_{2} \mathrm{O}$ and $\mathrm{CH}_{4}$ formation probably because of the restricted aeration at the injected slurry treatment (Flessa and Besse, 2000; Wulf et al., 2002). However, Dendooven et al. (1998) did not find differences in $\mathrm{N}_{2} \mathrm{O}$ and $\mathrm{CH}_{4}$ emission between injected and surface-applied pig slurry from loamy soil.

Development of a comprehensive understanding of the complexities of the interactions of soil/environmental/and management factors and their effects on the biology of $\mathrm{N}_{2} \mathrm{O}$ production and $\mathrm{CH}_{4}$ cycling is a daunting task. This work attempts to explore some of the interactions between soil type and $\mathrm{N}$ fertilization in controlled laboratory experiments using two different soils and three $\mathrm{N}$ fertility regimes. The specific objectives of this study were: (i) compare $\mathrm{N}_{2} \mathrm{O}, \mathrm{CO}_{2}$, and $\mathrm{CH}_{4}$ fluxes from soil receiving swine manure slurry and a commercial $\mathrm{N}$ source, and (ii) examine the interactive effects of soil type and $\mathrm{N}$ fertility treatment on $\mathrm{N}_{2} \mathrm{O}$ and $\mathrm{CH}_{4}$ emissions.

\section{Materials and Methods}

\section{Experimental Design}

The experiment was performed in a controlled environmental chamber programmed for a $14 \mathrm{~h}$ light period, $18^{\circ} \mathrm{C}$ day temperature, and $15^{\circ} \mathrm{C}$ night temperature. The treatments were organized in a randomized complete block design with $2 \times 3$ factorial arrangement of soil type and $\mathrm{N}$ source treatments. The soils were a sandy loam [classified as a Storden fine-loamy, mixed, mesic Typic Udorthents, (USDA, 1981)] and a clay [classified as a Webster fine-loamy, mixed, mesic Typic Haplaquolls, (USDA, 1981)]. The soils selected for the experiment were collected from Iowa State University Agriculture Experiment Station located in Boone County in central Iowa. Both soils had neutral $\mathrm{pH}$ although clayey soil had 2.5 times higher concentration of soil organic matter (SOC) and cation exchange capacity (CEC) than sandy soil (Table 1).

The $\mathrm{N}$ source treatments were: (i) control with no $\mathrm{N}$ source, (ii) urea-ammonium nitrate (UAN) fertilizer N, and (iii) swine manure slurry $\mathrm{N}$. The treatments were replicated four times and the experiment was conducted for $8 \mathrm{wk}$. The fertilizer $\mathrm{N}$ used was a UAN solution $\left(32 \% \mathrm{~N}\right.$ with density $\left.1.32 \mathrm{~g} \mathrm{~cm}^{-3}\right)$. The swine manure slurry was collected from manure storage tanks and contained $1.8 \mathrm{~g} \mathrm{~kg}^{-1}$ total $\mathrm{N}, 0.8 \mathrm{~g} \mathrm{~kg}^{-1}$ of ammonia $\mathrm{N}$, and $24 \mathrm{~g} \mathrm{~kg}^{-1}$ dry matter. Both $\mathrm{N}$ fertilizers were applied at a rate of $200 \mathrm{~kg} \mathrm{~N} \mathrm{ha}^{-1}$. Details of $\mathrm{N}$ application are provided below.

\section{Experiment Setup}

Plastic buckets ( $0.28 \mathrm{~m}$ in diameter and $0.35 \mathrm{~m}$ in height) containing soil without vegetation were used as the experimental
Table 1. Properties of soil used in this experiment.

\begin{tabular}{|c|c|c|}
\hline Properties & Sandy soil & Clayey soil \\
\hline $\mathrm{pH}$ & 6.9 & 7.0 \\
\hline Bulk density $\left(\mathrm{Mg} \mathrm{m}^{-3}\right)$ & $1.34(0.05) \dagger$ & $1.12(0.02)$ \\
\hline Sand ( $\mathrm{g} \mathrm{kg}^{-1}$ soil) & $789(12)$ & $216(7)$ \\
\hline Silt (g kg-1 soil) & $73(19)$ & $369(6)$ \\
\hline Clay (g kg ${ }^{-1}$ soil) & $138(13)$ & $415(13)$ \\
\hline \%WFPS at field capacity & 54 & 48 \\
\hline Soil organic C ( $\mathrm{g} \mathrm{kg}^{-1}$ soil) & $18.1(0.8)$ & $44.4(1.6)$ \\
\hline Dissolved organic C (mg kg${ }^{-1}$ soil) & $137(5)$ & $186(14)$ \\
\hline Total N (g kg-1 soil) & $1.75(0.10)$ & $3.63(0.20)$ \\
\hline $\mathrm{NO}_{3}^{-}\left(\mathrm{mg} \mathrm{N} \mathrm{kg}^{-1}\right.$ soil $)$ & $13.5(6.5)$ & $26.7(8.3)$ \\
\hline $\mathrm{NH}_{4}^{+}\left(\mathrm{mg} \mathrm{N} \mathrm{kg}^{-1}\right.$ soil $)$ & $0.11(0.18)$ & $0.13(0.30)$ \\
\hline CEC $\left(\mathrm{cmol}_{\mathrm{c}} \mathrm{kg}^{-1}\right.$ soil $)$ & $10.6(0.4)$ & $26.7(0.7)$ \\
\hline
\end{tabular}

† Standard deviation of triplicate analyses.

units. Each bucket was equipped with a drainage system consisting of a $48 \mathrm{~mm}$ diameter and $60 \mathrm{~mm}$ long ceramic cup placed at the bottom with an air entry value of $50 \mathrm{kPa}$. The end of the ceramic cup was sealed with a rubber stopper which had plastic tubing inserted through its center to connect later to a vacuum pump that maintained a vacuum of $9.8 \mathrm{kPa}$ and pulled any water that was collected in the ceramic cup into a collection flask. The bottom of the bucket and the ceramic cup were covered by $5 \mathrm{~kg}$ of coarse sand on which $12 \mathrm{~kg}$ of air-dried soil was placed. At the first watering, the buckets with soil and sand were treated with $4000 \mathrm{~mL}$ of $0.005 \mathrm{~mol} \mathrm{~L}^{-1} \mathrm{CaCl}_{2}$ to prevent soil aggregate dispersion. Suction was applied to the ceramic candles, the soil surface in each bucket was covered with plastic, and the buckets were allowed to equilibrate for $24 \mathrm{~h}$. After $24 \mathrm{~h}$ the buckets were weighed to determine water content at field capacity. At weekly intervals throughout the incubation, the buckets were weighed, the soil water content of each bucket was calculated, and water added to rewet the soil to field capacity. Percent water-filled pore space (\%WFPS) was calculated from measurements of bulk density and soil water content. At field capacity the \%WFPS for the sandy loam and clay soils were 54 and 49\%, respectively.

\section{Swine Manure Slurry and UAN}

Manure slurry was applied by cutting a $5 \mathrm{~cm}$ wide $\times 5 \mathrm{~cm}$ deep trench into the soil surface, pouring slurry $(684 \mathrm{~mL})$ into the furrow, and covering it with the soil previously removed from the trench. A UAN solution $\left(0.211 \mathrm{~g} \mathrm{~N} \mathrm{~mL}^{-1}\right)$ was injected at two points in each bucket $(2.92 \mathrm{~mL}$ per point). There was a $15 \mathrm{~cm}$ separation between the two injection points. This method of application was chosen to simulate field application of UAN with a spoke injector. Additional water $(680 \mathrm{~mL})$ was surface applied to the UAN and control treatments to match the amount of liquid applied in the swine manure slurry.

\section{Greenhouse Gas Emissions}

Greenhouse gases flux measurements were performed every day over the first $2 \mathrm{wk}$ and every second day over the remaining period by placing vented PVC chambers $(30 \mathrm{~cm}$ diameter $\times 10$ $\mathrm{cm}$ tall) on the buckets, and collecting gas samples at 0,30 , and 60 min following chamber deployment. Gas samples were taken by $10 \mathrm{~mL}$ polypropylene syringes and immediately injected into evacuated glass vials $(6 \mathrm{~mm})$ fit with butyl rubber stoppers. Gas 

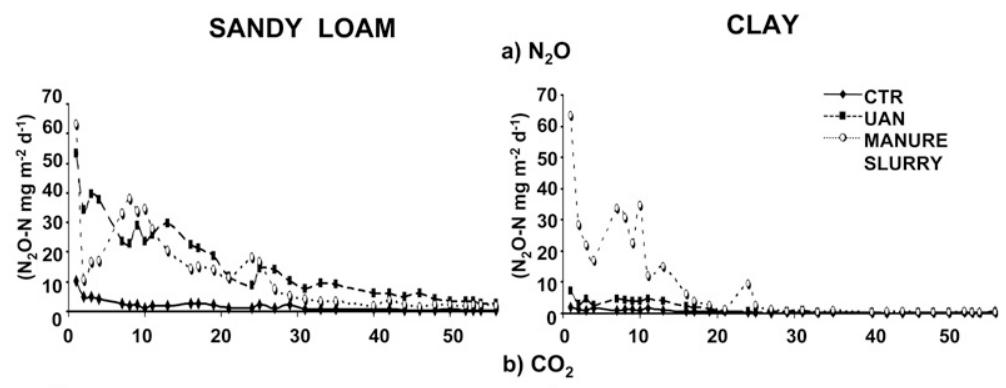

\section{Statistical Analyses}

Soil effects, $\mathrm{N}$ effects, and soil $\times \mathrm{N}$ treatment interactions on the cumulative GHG emissions were analyzed by two-way ANOVA. Individual contrasts were determined by Fisher's LSD method using SigmaStat software (SigmaStat Version 2.03; SPSS, 1997).

\section{Results}
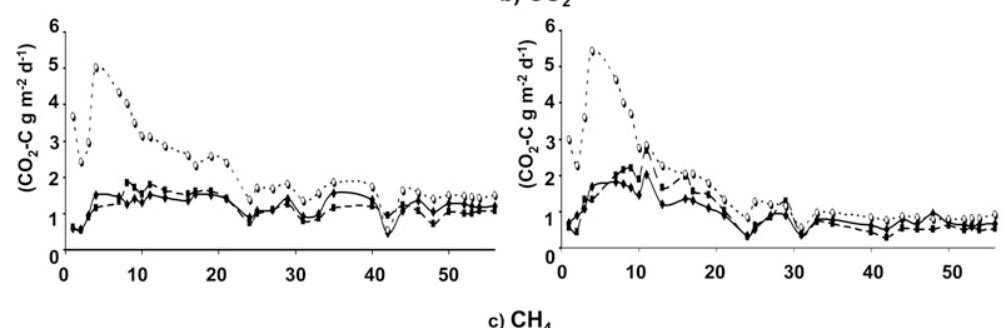

\section{Temporal Dynamics of GHG Emissions}

Daily $\mathrm{N}_{2} \mathrm{O}$ emission varied from $<0.5$ to $63 \mathrm{mg}$ $\mathrm{N}_{2} \mathrm{O}-\mathrm{N} \mathrm{m}^{-2} \mathrm{~d}^{-1}$ (Fig. 1a). Highest emissions were observed from the manure-treated soils. Fluxes from this treatment were highest at the time of manure application. Emissions then rapidly declined over the next 2 to $3 \mathrm{~d}$, but exhibited increases at day 7 , following the first watering event. Following subsequent weekly watering events, peaks of $\mathrm{N}_{2} \mathrm{O}$ emissions were observed; however, the amplitudes of these peaks decreased over the course of the incubation. Patterns of $\mathrm{N}_{2} \mathrm{O}$ emissions in the UAN treatment differed as a function of soil type. In the sandy loam-UAN treatment the $\mathrm{N}_{2} \mathrm{O}$ emission pattern was similar to that of the manure treatment; showing an initial peak followed by a general decline, punctuated by additional smaller peaks following watering events. The UAN treatment in the clay soil exhibited $\mathrm{N}_{2} \mathrm{O}$ emissions that remained below $10 \mathrm{mg} \mathrm{N} \mathrm{O}_{2}-\mathrm{N} \mathrm{m}^{2} \mathrm{~d}^{-1}$ throughout the entire experiment.

Patterns of $\mathrm{CO}_{2}$ emissions were similar between the two soils (Fig. 1b). Highest $\mathrm{CO}_{2}$ emissions were observed in the manure treatment, which exhibited peak flux $4 \mathrm{~d}$ after manure application. However, decline in $\mathrm{CO}_{2}$ emission was more rapid in the clay soil than in the sandy loam soil. In both soils, the

samples were analyzed for $\mathrm{N}_{2} \mathrm{O}, \mathrm{CO}_{2}$, and $\mathrm{CH}_{4}$ with an SRI gas chromatograph and introduced into the gas chromatograph using an auto sampler described by Arnold et al. (2001). Nitrous oxide was measured using a ${ }^{63} \mathrm{Ni}$ electron capture detector (ECD), with a stainless steel column (HaySepD, $0.3175 \mathrm{~cm}$ diameter $\times 74.54$ $\mathrm{cm}$ long). Methane and $\mathrm{CO}_{2}$ were analyzed with a flame ionization detector (FID) and a $90 \times 0.3 \mathrm{~cm}$ Hayesep D column (Alltech, Deerfield, IL). Nitrogen was used as a carrier gas at the flow rate of $20 \mathrm{~mL} \mathrm{~min}^{-1}$, and $\mathrm{H}_{2}\left(25 \mathrm{~mL} \mathrm{~min}^{-1}\right)$ and hydrocarbon-free air $\left(300 \mathrm{~mL} \mathrm{~min}^{-1}\right)$ were used as flame gases for $\mathrm{CH}_{4}$ analysis. Carbon dioxide was measured using the same flame ion detector by first directing gas samples through a methanizer (SRI, Torrance, CA). Oven, FID, and ECD detector temperatures were 50, 150, and $330^{\circ} \mathrm{C}$, respectively.

Gas fluxes were calculated from the time vs. concentration data using either linear regression or, when the time vs. concentration data were curvilinear, the algorithm of Hutchinson and Mosier (1981). These data were used to calculate cumulative emissions over the experimental period by linear interpolation and numerical integration using the trapezoid rule. To examine the relationship between \%WFPS and $\mathrm{N}_{2} \mathrm{O}$ emissions, we estimated the \%WFPS values by linear interpolation at times when the fluxes were measured. $\mathrm{CO}_{2}$ emissions in the UAN treatment were not significantly different than the control treatment.

Methane fluxes were variable, and in every treatment, except for the sandy soil treated with manure slurry, daily emissions were not significantly different from the fluxes in the control plots (Fig. 1c). Methane flux from the sandy loam soil treated with manure slurry exhibited a peak immediately after manure application, and another peak at the first watering event at $7 \mathrm{~d}$. Emissions then decreased over the course of the experiment.

During the course of the experiment water was added at weekly intervals. This resulted in weekly fluctuations in \%WFPS that ranged from 40 to $56 \%$ in the sandy soil and from 37 to $50 \%$ in the clay soil (Fig. 1d). The differences in maximum and minimum \%WFPS are due to bulk density differences between the two soils and the differences in soil water content at field capacity. It is interesting to note that trace gas fluxes seem to respond to the fluctuations in \%WFPS early in the experiment, but at the later stages of the experiment the amplitudes of the trace gas responses to added water (and increases in \%WFPS) diminished. In both soils there is substantial scatter in the relationship between \%WFPS and $\mathrm{N}_{2} \mathrm{O}$ flux (Fig. 2). Correlation analyses for the individual $\mathrm{N}$ treatments 


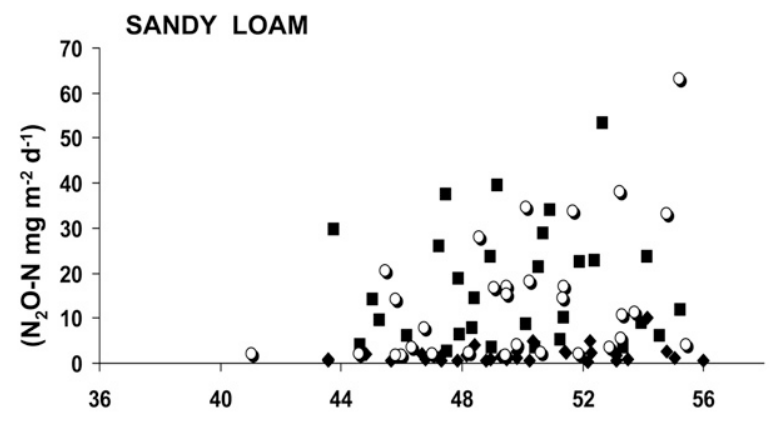

$\%$ WFPS

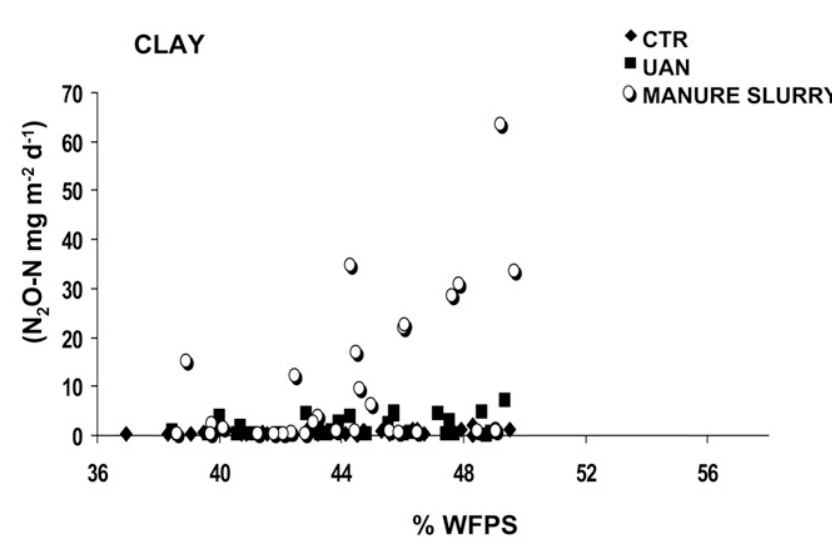

Fig. 2. Relationships between water-filled pore space and $\mathrm{N}_{2} \mathrm{O}$ emissions.

within each soil type were not significant and correlation coefficients ranged between 0.010 and 0.209 .

\section{Cumulative Greenhouse Gas Emissions}

There were significant soil and treatment differences in cumulative $\mathrm{N}_{2} \mathrm{O}$ emissions (Table 2). Nitrous oxide emissions in the control treatment of sandy loam and clay soils were not significantly different; however, in the UAN and manure treatments, the sandy loam had significantly greater cumulative $\mathrm{N}_{2} \mathrm{O}$ emissions than the clay soil. Within each soil type, there were also treatment differences. Cumulative $\mathrm{N}_{2} \mathrm{O}$ emissions in the sandy soil were greatest in the UAN treatment and smallest in the control. In the clay soil higher cumulative $\mathrm{N}_{2} \mathrm{O}$ emissions were observed in the manure treatment than in either the UAN or the control treatments. In addition to the soil and treatment differences, the soil $\times$ treatment interaction was also significant $(P=0.029)$. After accounting for the cumulative $\mathrm{N}_{2} \mathrm{O}-\mathrm{N}$ produced in the control treatments, it is calculated that, in the sandy loam, $\mathrm{N}_{2} \mathrm{O}-\mathrm{N}$ emissions accounted for the equivalent of $3.3 \%$ of the UAN nitrogen added and the equivalent of $2.7 \%$ of the manure $\mathrm{N}$ added with no significant differences between these values (Fig. 3). The clay-UAN treatment lost the least equivalent of $0.24 \%$ of the added $\mathrm{N}$, and the clay-manure treatment lost a larger equivalent of $1.84 \%$ of added manure $\mathrm{N}$ as $\mathrm{N}_{2} \mathrm{O}$ (Fig. 3). However, it was less than in the sandy loam-manure and sandy loam-UAN treatments.

Carbon dioxide emissions showed significant soil and treatment effects; however, the soil $\times$ treatment interaction was not significant (Table 3). In each treatment, cumulative $\mathrm{CO}_{2}$ emissions
Table 2. Effects of soil type and $\mathrm{N}$ fertility treatment on cumulative $\mathrm{N}_{2} \mathrm{O}$ emissions. Values are means of four replicates. Associated standard deviations are shown in parentheses. Probabilities in the right hand column indicate significance of soil effects within the given $\mathrm{N}$ treatment. The ANOVA table is presented below, and shows significance of soil $\mathrm{x} N$ treatment interaction.

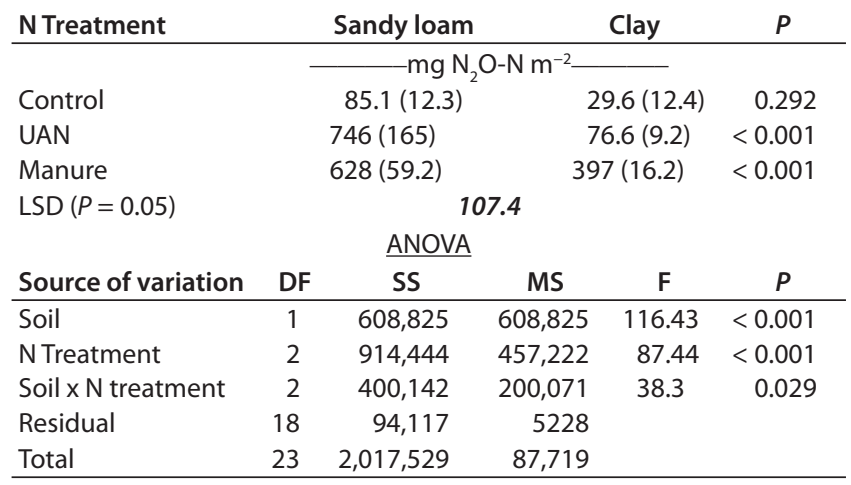

were significantly greater in the sandy soil than the clay soil. With respect to $\mathrm{N}$ treatment differences, within each soil, cumulative $\mathrm{CO}_{2}$ emissions from the UAN treatment and the control were not significantly different in either soil. However, in both soils the manure treatment had higher cumulative $\mathrm{CO}_{2}$ emissions than the other treatments. These elevated $\mathrm{CO}_{2}$ emissions in the manure treatment were likely due to the added organic $\mathrm{C}$. The dry matter content of the manure used in this experiment was $24 \mathrm{~g} \mathrm{~kg}^{-1}$. If it is assumed that the $\mathrm{C}$ content of the dry matter was $400 \mathrm{~g} \mathrm{~kg}^{-1}$, the application rate of particulate $\mathrm{C}$ in the manure treatments of this study was approximately $106 \mathrm{~g} \mathrm{C} \mathrm{m}^{-2}$. In the sandy soil the difference in cumulative $\mathrm{CO}_{2}-\mathrm{C}$ emissions between the control and manure treatments was $48.5 \mathrm{~g} \mathrm{C} \mathrm{m}^{-2}$, and in the clay soil the manure treatment produced $38.1 \mathrm{~g} \mathrm{CO}_{2}-\mathrm{C} \mathrm{m}^{-2}$ more than the control treatment. Thus, in the $8 \mathrm{wk}$ of this study the equivalent of $45.5 \%$ of the added particulate manure $\mathrm{C}$ was lost from the sandy soil, and $35.7 \%$ was lost from the clay soil.

Cumulative $\mathrm{CH}_{4}$ fluxes are presented in Table 4. Only the sandy loam-manure treatment had cumulative $\mathrm{CH}_{4}$ fluxes that were significantly different from other treatments. The results from ANOVA analysis indicated both a significant soil effect and $\mathrm{N}$ treatment effect, as well as a significant soil $\times$ $\mathrm{N}$-treatment interaction.

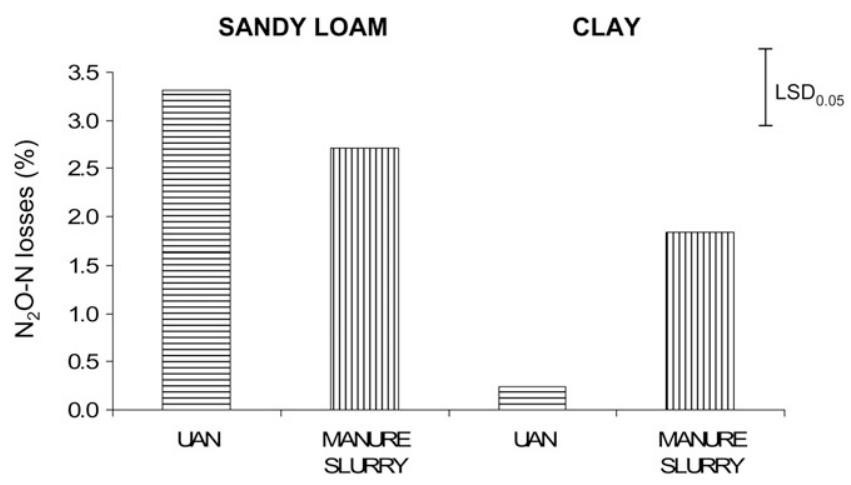

Fig. 3. Percentages of added $\mathrm{N}$ lost as $\mathrm{N}_{2} \mathrm{O}$ emission from sandy loam and clayey soils fertilized with UAN or manure slurry applied at the rate of $200 \mathrm{~kg} \mathrm{~N} \mathrm{ha}^{-1}$. Error bar indicates $\mathrm{LSD}_{0.05^{\circ}}$ 
Table 3. Effects of soil type and $\mathrm{N}$ fertility treatment on cumulative $\mathrm{CO}_{2}$ emissions. Values are means of four replicates. Associated standard deviations are shown in parentheses. Probabilities in the right hand column indicate significance of soil effects within the given $\mathrm{N}$ treatment. The ANOVA table is presented below showing sources of variation.

\begin{tabular}{|c|c|c|c|c|c|}
\hline N Treatment & \multicolumn{3}{|c|}{ Sandy loam } & Clay & $P$ \\
\hline & \multicolumn{4}{|c|}{$-\mathrm{mg} \mathrm{CO}_{2}-\mathrm{C} \mathrm{m}^{-2}$} & \\
\hline Control & \multicolumn{3}{|c|}{$65.5(7.5)$} & $50.1(5.9)$ & 0.006 \\
\hline UAN & \multicolumn{3}{|c|}{$64.4(4.6)$} & 52.5 (1.9) & 0.027 \\
\hline Manure & \multicolumn{3}{|c|}{$114(10.5)$} & $88.2(5.6)$ & $<0.001$ \\
\hline $\operatorname{LSD}(P=0.05)$ & \multicolumn{4}{|c|}{7.36} & \\
\hline \multicolumn{6}{|c|}{ ANOVA } \\
\hline Source of variation & DF & SS & MS & $\mathbf{F}$ & $P$ \\
\hline Soil & 1 & 1908 & 1908 & 38.86 & $<0.001$ \\
\hline N Treatment & 2 & 9944 & 4972 & 101.3 & $<0.001$ \\
\hline Soil $x \mathrm{~N}$ treatment & 2 & 220 & 110 & 2.24 & 0.135 \\
\hline Residual & 18 & 884 & 49 & & \\
\hline Total & 23 & 12,956 & 563 & & \\
\hline
\end{tabular}

\section{Discussion}

Past observations of soil texture effects on $\mathrm{N}_{2} \mathrm{O}$ emissions have yielded mixed conclusions. Mkhabela et al. (2006) observed 2.5 times higher $\mathrm{N}_{2} \mathrm{O}$ emission from sandy loam soil than from silty clay loam soil. These authors attributed the differences to the fact that the sandy loam had higher $\mathrm{pH}$ (5.7) than their silty clay loam soil ( $\mathrm{pH}=4.7)$. Conversely, in a summary of studies reporting $\mathrm{N}_{2} \mathrm{O}$ emissions in Eastern Canada, Gregorich et al. (2005) describe higher $\mathrm{N}_{2} \mathrm{O}$ emissions from a clay soil than a loamy sand. Similarily, Bouwman et al. (2002) reported that fine-textured soils high in $\mathrm{SOC}$ showed higher $\mathrm{N}_{2} \mathrm{O}$ emissions than less fertile soils. However, Bouwman (1996), in an analysis of $\mathrm{N}_{2} \mathrm{O}$ emissions from fertilized and unfertilized lands, reported on conflicting observations of the effects of soil texture on $\mathrm{N}_{2} \mathrm{O}$ emissions. He attributed the observations of higher $\mathrm{N}_{2} \mathrm{O}$ emissions in heavy textured soils to enhanced anaerobic conditions, whereas in lighter textured soils, it was speculated that weather conditions dominated any texture effects. Clearly, soil texture influences several factors that control $\mathrm{N}_{2} \mathrm{O}$ emissions, including aeration, organic $\mathrm{C}$ availability, and $\mathrm{N}$ availability. Thus, depend-

Table 4. Effects of soil type and $\mathrm{N}$ fertility treatment on cumulative $\mathrm{CH}_{4}$ fluxes. Values are means of four replicates. Associated standard deviations are shown in parentheses. Probabilities in the right hand column indicate significance of soil effects within the given $\mathrm{N}$ treatment. The ANOVA table is presented below, showing sources of variation.

\begin{tabular}{|c|c|c|c|c|c|}
\hline N Treatment & \multicolumn{3}{|c|}{ Sandy loam } & Clay & $P$ \\
\hline & \multicolumn{4}{|c|}{$-\mathrm{mgCH}_{4}-\mathrm{C} \mathrm{m}^{-2}$} & \\
\hline Control & \multicolumn{3}{|c|}{$-6.4(19.6)$} & $-5.9(4.9)$ & 0.98 \\
\hline UAN & \multicolumn{3}{|c|}{$13.6(32.6)$} & $-8.8(31.1)$ & 0.20 \\
\hline Manure & \multicolumn{3}{|c|}{$113(20.3)$} & $15.2(21.2)$ & $<0.001$ \\
\hline $\operatorname{LSD}(P=0.05)$ & \multicolumn{4}{|c|}{34.85} & \multirow[b]{3}{*}{$P$} \\
\hline & \multicolumn{2}{|c|}{$\underline{\text { ANOVA }}$} & \multirow[b]{2}{*}{ MS } & \multirow[b]{2}{*}{$\mathbf{F}$} & \\
\hline Source of variation & DF & SS & & & \\
\hline Soil & 1 & 9624 & 9624 & 17.48 & $<0.001$ \\
\hline N Treatment & 2 & 23,699 & 11,849 & 21.53 & $<0.001$ \\
\hline Soil $x \mathrm{~N}$ treatment & 2 & 10,685 & 5342 & 9.71 & 0.001 \\
\hline Residual & 18 & 9908 & 550 & & \\
\hline Total & 23 & 53,917 & 2344 & & \\
\hline
\end{tabular}

ing on the interplay of these controlling factors at the specific sites of $\mathrm{N}_{2} \mathrm{O}$ production in soil, it is not unreasonable to expect varied effects of texture on $\mathrm{N}_{2} \mathrm{O}$ emissions.

The sandy loam soil of our study exhibited higher emissions of $\mathrm{N}_{2} \mathrm{O}$ than the clay soil. There could be several texture-related factors contributing to this result. In our protocol, the water contents of our experimental units were adjusted to field capacity at weekly intervals. As a result of the bulk density differences between our two soils, there were differences in \%WFPS, with the sandy soil having higher average \% WFPS than the clay soil. Percent waterfilled pore space has been used as an indicator of soil aeration state (Linn and Doran, 1984). Davidson (1991) provided a general relationship between \%WFPS and $\mathrm{N}_{2} \mathrm{O}$ emissions. This relationship predicts net $\mathrm{N}_{2} \mathrm{O}$ emissions between \%WFPS values of 30 and 90 , with a peak $\mathrm{N}_{2} \mathrm{O}$ production occurring at approximately $65 \%$ WFPS. Within a given soil type, fertility regime, and cropping system this idealized relationship may be valid, but generalizations across soils and management systems are likely to be poor. Indeed, some recent studies report that $\mathrm{N}_{2} \mathrm{O}$ emissions do not exhibit a peak in the range of 60 to 65\% WFPS, but rather increase up to 80 to $90 \%$ WFPS (Adviento-Borbe et al., 2006; Maljanen et al., 2007). Unlike other laboratory studies investigating \%WFPS and $\mathrm{N}_{2} \mathrm{O}$ production, in our study \%WFPS was not held constant. In the early stages of our incubation, increases in $\mathrm{N}_{2} \mathrm{O}$ emissions were observed after water additions (and resulting increases in \%WFPS); however, the amplitudes of these $\mathrm{N}_{2} \mathrm{O}$ peaks following water addition diminished with time. Thus, over the course of our experiment we did not observe a strong relationship between \%WFPS and $\mathrm{N}_{2} \mathrm{O}$ emissions in either of our soils. This diminished response of $\mathrm{N}_{2} \mathrm{O}$ to changes in \%WFPS in the later stages of our incubations indicates that factors other than soil water content were limiting $\mathrm{N}_{2} \mathrm{O}$ emissions.

Differences in $\mathrm{N}$ availability in our two soils may have been a factor controlling $\mathrm{N}_{2} \mathrm{O}$ production. It is known that the composition of the soil mineral fraction as well as soil organic $\mathrm{C}$ can impact ammonium absorption (Bremner, 1959; Burge and Broadbent, 1961). In addition, it has been shown that decreased $\mathrm{N}$ availability due to ammonium fixation by soil colloids can reduce the activity of nitrifying bacteria (Hommes et al., 1998). De Visscher et al. (1998) demonstrated that increasing inputs of $\mathrm{NH}_{4}^{+}$to soil with low $\mathrm{CEC}$ was associated with higher $\mathrm{N}_{2} \mathrm{O}$ emissions. They concluded that soils with high CEC facilitated immobilization of $\mathrm{NH}_{4}^{+}$at cation exchange sites, whereas in soils with low CEC, higher concentrations of free $\mathrm{NH}_{4}{ }^{+}$were available. A recent study investigated the adsorption of manure $\mathrm{NH}_{4}^{+}$and ammonium sulfate $\mathrm{NH}_{4}^{+}$in two soils having different CECs (Fernando et al., 2005). These authors found that in a clay soil with a CEC of 20 $\mathrm{cmol} \mathrm{kg}{ }^{-1}$ and clay content of $20 \%$, sorption of swine manure slurry $\mathrm{NH}_{4}^{+}$was initially more rapid than $\left(\mathrm{NH}_{4}\right)_{2} \mathrm{SO}_{4}-\mathrm{NH}_{4}^{+}$, but after $80 \mathrm{~h}$ equilibrium sorbed $\mathrm{NH}_{4}^{+}$concentrations of both materials were approximately equal. Measured $\mathrm{NH}_{4}^{+}$adsorption maxima for each applied $\mathrm{N}$ material in each soil showed that the clay soil had $\mathrm{NH}_{4}^{+}$adsorption maxima of 1000 and $909 \mathrm{mg} \mathrm{NH}_{4}^{+} \mathrm{kg}^{-1}$ soil for the manure and $\left(\mathrm{NH}_{4}\right)_{2} \mathrm{SO}_{4}$ treatments, respectively. The $\mathrm{NH}_{4}^{+}$ adsorption maxima in the sandy soil $\left(\mathrm{CEC}=11 \mathrm{cmol} \mathrm{kg}^{-1}, 8 \%\right.$ clay) were lower $\left(625 \mathrm{mg} \mathrm{NH}_{4}^{+} \mathrm{kg}^{-1}\right.$ soil for the manure treatment 
and $217 \mathrm{mg} \mathrm{NH}_{4}^{+} \mathrm{kg}^{-1}$ soil for the $\left(\mathrm{NH}_{4}\right)_{2} \mathrm{SO}_{4}$ treatment). The greatest difference between their soils was in the $\left(\mathrm{NH}_{4}\right)_{2} \mathrm{SO}_{4}$ treatment. This was thought to be due to the fact that dissolved organic $\mathrm{C}$ in the manure served to promote $\mathrm{NH}_{4}^{+}$adsorption. Our results can be explained in the context of these authors' observations. Ammonium $\mathrm{N}$ sorption predicted from the texture-organic matter interactions described by Nishantha et al. (2005) would have resulted in $\mathrm{N}$ availability in our treatments as follows: sandy loam$\mathrm{UAN}>$ sandy loam-manure > clay-UAN > clay-manure. This order of predicted $\mathrm{N}$ availability was reflected in our observations of cumulative $\mathrm{N}_{2} \mathrm{O}$ loss in our sandy loam soil, but not in our clay soil. We observed cumulative $\mathrm{N}_{2} \mathrm{O}$ losses in the order: sandy loamUAN > sandy loam-manure > clay-manure > clay-UAN (Table 2). In our UAN treatment cumulative $\mathrm{N}_{2} \mathrm{O}$ losses were approximately ninefold greater in the sandy loam than in the clay soil. This effect could be due, at least in part, to the higher $\mathrm{NH}_{4}^{+}-\mathrm{N}$ adsorption in the clay, and thus, lower $\mathrm{N}$ availability. However, based on the results of Nishantha et al. (2005) it should be predicted that the lowest $\mathrm{NH}_{4}^{+}$availability would have been present in our clay-manure treatment. Yet this treatment had cumulative $\mathrm{N}_{2} \mathrm{O}$ emissions that were greater than the clay-UAN treatment. The unknown factor possibly contributing to this apparent discrepancy is the susceptibility of the sorbed organo- $\mathrm{NH}_{4}^{+}$complexes to microbial decomposition. Also, it should be recognized that $\mathrm{NH}_{4}^{+}$comprised only $44 \%$ of the added $\mathrm{N}$ in the manure slurry treatment, thus the organic $\mathrm{N}$ in the manure may have been a source for $\mathrm{N}_{2} \mathrm{O}$ production. We observed enhanced $\mathrm{CO}_{2}$ production in the manure slurry treatments relative to the UAN treatments (Table 4), indicating that organic material in the manure was being decomposed. It is likely that some of this $\mathrm{N}$ released might have been available to nitrifying or denitrifying organisms.

Differences in $\mathrm{N}$ availability within our soil-treatment combinations are also consistent with our observed differences in $\mathrm{CH}_{4}$ emissions. $\mathrm{Net}^{\mathrm{CH}_{4}}$ emissions from soil are the result of two competing processes; methanogenesis and methane oxidation. Several studies have shown that $\mathrm{CH}_{4}$ oxidation is lower in agricultural soils than in natural systems (Bender and Conrad, 1993; Dobbie and Smith, 1996; Powlson et al., 1997). This effect, in part, is thought to be due to fertilizer $\mathrm{N}$ inhibition of $\mathrm{CH}_{4}$ consumption activity in arable soils (Steudler et al., 1989; Mosier et al., 1991; Bronson and Mosier, 1994). Indeed, $\mathrm{NH}_{4}^{+}$has been reported to be a competitive inhibitor of $\mathrm{CH}_{4}$ oxidation (Whittenbury et al., 1970; Hyman and Wood, 1983; Jones and Morita, 1983). However, the response of methane oxidation to $\mathrm{N}$ additions may be moderated by soil texture. It has been observed that inhibition of methane oxidation in response to $\mathrm{N}$ additions was greater in a sandy loess soil than in a clay soil (Hütsch et al., 1993; Hütsch, 1996). Similarly, the differences in CEC in our sandy and clay soils could have impacted free $\mathrm{NH}_{4}^{+}$concentrations that, in turn, could have had a differential effect on $\mathrm{CH}_{4}$ oxidation (De Visscher et al., 1998). However, net $\mathrm{CH}_{4}$ emissions are also dependant on $\mathrm{CH}_{4}$ production. Manure applications to soil, in addition to providing an inoculum of methanogenic bacteria, stimulate $\mathrm{O}_{2}$ consumption and facilitate the development of anaerobic conditions. Manure slurry has been observed to promote $\mathrm{CH}_{4}$ fluxes immediately after application to the soil (Sommer et al., 1996; Chadwick et al., 2000; Chan and
Parkin, 2001a; Sherlock et al., 2002) and in response to rainfall events following manure applications (Chan and Parkin, 2001a). Thus, in combination with the inhibitory effects of manure $\mathrm{NH}_{4}^{+}$ on methane oxidation, stimulation of $\mathrm{CH}_{4}$ production in soil by manure would tend to increase net $\mathrm{CH}_{4}$ emissions. In our study, we observed significant $\mathrm{CH}_{4}$ fluxes from the sandy loam soil in response to manure application. In our other treatments cumulative $\mathrm{CH}_{4}$ fluxes were not significant from zero.

\section{Conclusions}

Manure additions to the sandy loam soil significantly increased $\mathrm{CH}_{4}$ emissions. However, methane emissions from other treatments were not significantly different from zero. We observed a significant soil effect on cumulative $\mathrm{N}_{2} \mathrm{O}$ emissions. The lack of a significant relationship between \%WFPS indicates that $\mathrm{N}$ availability may be a primary mechanism controlling $\mathrm{N}_{2} \mathrm{O}$ emissions. We also observed a significant soil type $\times \mathrm{N}$ treatment interaction. We speculate that differences in $\mathrm{NH}_{4}^{+}$fixation between the two soils could be a factor controlling $\mathrm{N}$ availability for $\mathrm{N}_{2} \mathrm{O}$ production. The significant soil $\times \mathrm{N}$ treatment interaction may have relevance to current efforts aimed at prediction of $\mathrm{N}_{2} \mathrm{O}$ emissions.

\section{References}

Adviento-Borbe, M.A.A., J.W. Doran, R.A. Drijber, and A. Dobermann. 2006. Soil electrical conductivity and water content affect nitrous oxide and carbon dioxide emissions in intensively managed soils. J. Environ. Qual. 35:1999-2010.

Arnold, S., T.B. Parkin, J.W. Doran, and A.R. Mosier. 2001. Automated gas sampling system for laboratory analysis of $\mathrm{CH}_{4}$ and $\mathrm{N}_{2} \mathrm{O}$. Commun. Soil Sci. Plant Anal. 32:2795-2807.

Bender, M., and R. Conrad. 1993. Kinetics of methane oxidation in oxic soils. Chemosphere 26:687-696.

Bouwman, A.F. 1996. Direct emissions of nitrous oxide from agricultural soils. Nutr. Cycling Agroecosyst. 46:53-70.

Bouwman, A.F., L.J.M. Boumans, and N.H. Batjes. 2002. Emissions of $\mathrm{N}_{2} \mathrm{O}$ and NO from fertilized fields: Summary of available measurement data. Global Biogeochem. Cycles 16:1-13.

Breitenbeck, G.A., A.M. Blackmer, and J.M. Bremner. 1980. Effects of different nitrogen fertilizers on emission of nitrous oxide from soil. Geophys. Res. Lett. 7:85-88.

Bremner, J.M. 1959. Determination of fixed ammonium in soil. J. Agric. Sci. 52:137-146.

Bremner, J.M., G.A. Breitenbeck, and A.M. Blackmer. 1981. Effect of anhydrous ammonia fertilization on emission of nitrous oxide from soils. J. Environ. Qual. 10:77-80.

Bronson, K.S., and A.R. Mosier. 1994. Suppression of methane oxidation in aerobic soil by nitrogen fertilizers, nitrification inhibitors, and urease inhibitors. Biol. Fertil. Soils 17:263-268.

Burge, W.D., and F.E. Broadbent. 1961. Fixation of ammonia by organic soils. Soil Sci. Soc. Am. Proc. 25:199-204.

Cameron, K.C., F.M. Kelliher, R.R. Sherlock, E.A. Forbes, and C.A.M. de Klein. 2000. Nitrous oxide inventory and mitigation. A National Science Strategy Research Programme for New Zealand- Report for MAF-Policy Wellington. $146 \mathrm{p}$.

Chadwick, D.R., B.F. Pain, and S.K.E. Brookman. 2000. Nitrous oxide emission following application of animal manures to grassland. J. Environ. Qual. 29:277-287.

Chan, A.S.K., and T.B. Parkin. 2001a. Effect of land use on methane flux from soil. J. Environ. Qual. 30:786-797.

Chan, A.S.K., and T.B. Parkin. 2001b. Methane oxidation and production activity in soils from natural and agricultural ecosystems. J. Environ. Qual. 30:1896-1903.

Comfort, S.D., K.A. Kelling, D.R. Keeney, and J.C. Converse. 1990. Nitrous oxide production from injected liquid dairy manure. Soil Sci. Soc. Am. J. 
54:421-427.

Conrad, R. 1996. Soil microorganisms as controllers of atmospheric trace gases $\left(\mathrm{H}_{2}\right.$, $\mathrm{CO}, \mathrm{CH}_{4}, \mathrm{OCS}, \mathrm{N}_{2} \mathrm{O}$, and NO). Microbial. Rev. 60:609-640.

Dalal, R.C., W. Wang, P.G. Robertson, and W.J. Parton. 2003. Nitrous oxide emission from Australian agricultural lands and mitigation options: A review. Aust. J. Soil Res. 41:165-195.

Davidson, E.A. 1991. Fluxes of nitrous oxide and nitric oxide from terrestrial ecosystems. p. 219-235. In J.E. Rogers and B.W. Whitman (ed.) Methane, nitrogen oxides, and Halomethanes. American Society for Microbiology, Washington, DC.

de Klein, C.A.M., R.R. Sherlock, K.C. Cameron, and T.J. van der Weerden. 2001. Nitrous oxide emissions from agricultural soils in New Zealand- A review of current knowledge and directions for future research. J. R. Soc. N. Z. 31:543-574.

De Visscher, A., P. Boeckx, and O. Van Cleemput. 1998. Interaction between nitrous oxide formation and methane oxidation in soils: Influence of cation exchange phenomena. J. Environ. Qual. 27:679-687.

Dendooven, L., E. Bonhomme, and R. Merckx. 1998. Injection of pig slurry and its effect on dynamics of nitrogen and carbon in loamy soil under laboratory conditions. Biol. Fertil. Soils 27:5-8.

Dobbie, K.E., and K.A. Smith. 1996. Comparison of $\mathrm{CH}_{4}$ oxidation refer rates in woodland, arable, and set aside soils. Soil Biol. Biochem. 28:1357-1365.

Eichner, M.J. 1990. Nitrous oxide emissions from fertilized soils: Summary of available data. J. Environ. Qual. 19:272-280.

Fernando, W.A.R.N., K. Xia, and C.W. Rice. 2005. Sorption and desorption of ammonium from liquid swine waste in soils. Soil Sci. Soc. Am. J. 69:1057-1065.

Flessa, H., and F. Besse. 2000. Laboratory estimates of trace gas emission following surface application and injection of cattle slurry. J. Environ. Qual. 29:262-268.

Gregorich, E.G., P. Rochette, A.J. VandenBygaart, and D.A. Angers. 2005. Greenhouse gas contributions of agricultural soils and potential mitigation practices in Eastern Canada. Soil Tillage Res. 83:53-72.

Hatfield, J., M.C. Brumm, and S.W. Melvin. 1998. Swine manure management p. 78-90. In R.J. Wright et al. (ed.) Agricultural uses of municipal, animal, and industrial byproducts. Conservation Research Rep. No. 44. USDA-ARS, Washington, DC.

Hommes, N.G., S.A. Russell, B.J. Bottomley, and D.J. Arp. 1998. Effects of soil on ammonia, ethylene, chloroethane, and 1,1,1-Trichloroethane oxidation by Nitrosomonas europaea. Appl. Environ. Microbiol. 64:1372-1378.

Hutchinson, G.L., and A.R. Mosier. 1981. Improved soil cover method for field measurement of nitrous oxide fluxes. Soil Sci. Soc. Am. J. 45:311-316.

Hütsch, B.W. 2001. Methane oxidation in non-flooded soils as affected by crop production. Eur. J. Agron. 14:237-260.

Hütsch, B.W. 1996. Methane oxidation in soils of two long-term fertilization experiments in Germany. Soil Biol. Biochem. 28:773-782.

Hütsch, B.W., C.P. Webster, and D.S. Powlson. 1993. Long-term effects of nitrogen fertilization in soil of the Broadbalk wheat experiment. Soil Biol. Biochem. 25:1307-1315.

Hyman, M.R., and P.M. Wood. 1983. Methane oxidation by Nitrosomonas europaea. Biochem. J. 212:31-37.

IPCC. 2006. Guidelines for national greenhouse gas inventories. In S. Eggleston et al. (ed.) Available at http://www.ipcc-nggip.iges.or.jp/public/2006gl/index. htm (verified 7 Apr. 2008). IPCC, Geneva, Switzerland.

Isermann, K. 1994. Agriculture's share in the emission of trace gases affecting the climate and some case-oriented proposals for sufficiently reducing this share. Environ. Pollut. 83:95-111.

Janzen, H.H., R.L. Desjardins, J.R.M. Asselin, and B. Grace. 1998. The health of our air. Toward sustainable agriculture in Canada. Agriculture and Agri-Food Canada. Research Branch, Ottawa, ON, Canada.

Jones, R.D., and R.Y. Morita. 1983. Methane oxidation by Nitrococcus oceanus and Nitrosomonas europaea. Appl. Environ. Microbiol. 45:401-410.

Kaiser, E.A., K. Kohrs, M. Kücke, E. Schung, O. Heinemeyer, and J.C. Munch. 1998. Nitrous oxide release from arable soil: Importance of $\mathrm{N}$ - fertilization, crops, and temporal variation. Soil Biol. Biochem. 30:1553-1563.

Kaiser, E.A., and R. Ruser. 2000. Nitrous oxide emissions from arable soils in Germany- An evaluation of six long-term field experiments. J. Plant Nutr. Soil Sci. 163:249-259.

Le Mer, J., and P. Roger. 2001. Production, oxidation, emission, and consumption of methane by soils: A review. Eur. J. Soil Biol. 37:25-50.

Linn, D.M., and J.W. Doran. 1984. Effect of water-filled pore space on carbon dioxide and nitrous oxide production in tilled and nontilled soils. Soil Sci. Soc. Am. J. 48:1267-1272.

Maljanen, M., M. Martikkala, H.T. Koponen, P. Virkajärvi, and P.J. Martikainen. 2007. Fluxes of nitrous oxide and nitric oxide from experimental excreta patches in boreal agricultural soil. Soil Biol. Biochem. 39:914-920.

McSwiney, C.P., and G.P. Robertson. 2005. Nonlinear response of $\mathrm{N}_{2} \mathrm{O}$ flux to incremental fertilizer addition in a continuous maize (Zea mays L.) cropping system. Glob. Change Biol. 11:1712-1719.

Mkhabela, M.S., R. Gordon, D. Burton, A. Madani, W. Hart, and A. Elmi. 2006 Ammonia and nitrous oxide emissions from two acidic soils of Nova Scotia fertilized with liquid hog manure mixed with or without dicyandiamide. Chemosphere 65:1381-1387.

Mosier, A.R., and T. Parkin. 2007. Gaseous emissions $\left(\mathrm{CO}_{2}, \mathrm{CH}_{4}, \mathrm{~N}_{2} \mathrm{O}\right.$, and NO) from diverse agricultural production systems. p. 317-348. In $\mathrm{G}$. Benckiser and S. Schnell (ed.) Biodiversity in agricultural production systems. CRC Press/Taylor and Francis, Boca Raton, FL.

Mosier, A.R., J.M. Duxbury, J.R. Freney, O. Heinmeyer, and K. Minami. 1998. Assessing and mitigating $\mathrm{N}_{2} \mathrm{O}$ emissions from agricultural soils. Clim. Change 40:7-38.

Mosier, A.R., G.L. Hutchinson, B.R. Sabey, and J. Baxter. 1982. Nitrous oxide emission from barley plots treated with ammonium nitrate or sewage sludge. J. Environ. Qual. 11:78-81.

Mosier, A., D. Schimel, D. Valentine, K. Bronson, and W. Parton. 1991. Methane and nitrous oxide fluxes in native fertilized and cultivated grasslands. Nature 350:330-332.

Nishantha, W.A.R., Kang Xia, F., and C.W. Rice. 2005. Sorption and desorption of ammonium from liquid swine waste in soils. Soil Sci. Soc. Am. J. 69:1057-1065.

Petersen, S.O. 1999. Nitrous oxide emission from manure and inorganic fertilizers applied to spring barley. J. Environ. Qual. 28:1610-1618.

Powlson, D.S., K.W.T. Goulding, T.W. Willison, C.P. Webster, and B.W. Hütsch. 1997. The effect of agriculture on methane oxidation in soil. Nutr. Cycling Agroecosyst. 49:59-70.

Rochette, P., E. van Bochove, D. Prévost, A.D. Angers, D. Côté, and N. Bertrand. 2000. Soil carbon and nitrogen dynamics following application of pig slurry for the 19th consecutive year: II. Nitrous oxide fluxes and mineral nitrogen. Soil Sci. Soc. Am. J. 64:1396-1403.

Schimel, J.P., and J. Gulledge. 1998. Microbial community structure and global trace gases. Glob. Change Biol. 7:745-758.

Sherlock, R.R., S.G. Sommer, Z.R. Khan, C.W. Wood, E.A. Guertal, J.R. Freney, C.O. Dawson, and K.C. Cameron. 2002. Ammonia, methane, and nitrous oxide emission from pig slurry applied to a pasture in New Zealand. J. Environ. Qual. 31:1491-1502.

Smith, K.A., K.E. Dobbie, B.C. Ball, L.R. Bakken, B.K. Sitaula, S. Hansen, R. Brummie, W. Borken, S. Christensen, A. Priemè, D. Flower, J.A. MacDonald, U. Skiba, L. Klemedtsson, L.A. Kasimir-Klemedtsson, A. Degòrska, and P. Orlanski. 2000. Oxidation of atmospheric methane in Northern European soils, comparison with other ecosystems, and uncertainties in the global terrestrial sink. Glob. Change Biol. 6:791-803.

Sommer, S.G., R.R. Sherlock, and R.Z. Khan. 1996. Nitrous oxide and methane emissions from pig slurry amended soils. Soil Biol. Biochem. 28:1541-1544.

SPSS. 1997. SigmaStat 2.03 for Windows. SPSS Inc., Chicago, IL.

Steudler, P.A., R.D. Bowden, J.M. Melillo, and J.D. Aber. 1989. Influence of nitrogen fertilization on methane uptake in temperate forest soils. Nature 341:314-315.

Suwanwaree, P., and G.P. Robertson. 2005. Methane oxidation in forest and no-till agricultural ecosystems: Effects of nitrogen and soil disturbance. Soil Sci. Soc. Am. J. 69:1722-1729.

USDA. 1981. Soil survey of Boone County. Soil Conservation Service, IA.

Whittenbury, R., K.C. Phillips, and J.F. Wilkinson. 1970. Enrichment, isolation, and some properties of methane-utilizing bacteria. J. Gen. Microbiol. 61:205-218.

Wulf, S., M. Maeting, and J. Clemens. 2002. Application technique and slurry cofermentation effects on ammonia, nitrous oxide, and methane emissions after spreading: II. Greenhouse gas emissions. J. Environ. Qual. 31:1795-1801.

Yamulki, S., and S.C. Jarvis. 2002. Short-term effects of tillage and compaction on nitrous oxide, nitric oxide, nitrogen dioxide, methane, and carbon dioxide fluxes from grassland. Biol. Fertil. Soils 36:224-231. 